УДК $159.9: 376.1$

DOI https://doi.org/10.32782/apv/2021.5.23

\title{
Тамара ІЛЛЯШЕНКО
}

кандидат психологічних наук, старший науковий співробітник, провідний науковий співробітник, Украӥнський науково-методичний центр практичної психологї̈ і соиіальної роботи, провул. ВітоЛитовський, 98А, м. Київ, Україна, 03045

ORCID: 0000-0002-5954-6177

Бібліографічний опис статті: Ілляшенко, Т. (2021). Проблеми впровадження інклюзивного навчання дітей з особливими освітніми потребами в Україні. Acta Paedagogica Volynienses, 5, 150-157, doi: https://doi.org/10.32782/apv/2021.5.23

\section{ПРОБЛЕМИ ВПРОВАДЖЕННЯ ІНКЛЮЗИВНОГО НАВЧАННЯ ДІТЕЙ З ОСОБЛИВИМИ ОСВІТНІМИ ПОТРЕБАМИ В УКРАЇНІ}

У статті розглядаються питання організаційно-методичного забезпечення інклюзивного навчання дітей з особливими освітніми потребами (ООП), яке активно впроваджується в Украӥні.

На основі аналізу та узагальнення досліджень і публікацій констатовано недосконалість сьогоднішнього інклюзивного навчання в Украӥні, зумовлену економічними, організаційно-методичними чинниками, зокрема екстраполяцією зарубіжного досвіду та труднощами його адаптації у вітчизняних умовах. Узв'язку з цим у статті поставлена мета проаналізувати стан організаційно-методичного забезпечення інклюзивного навчання в Україні та внести пропозиції щзодо його оптимізації.

Виходячи з висвітленого у прачях вітчизняних дослідників світового досвіду інклюзивного навчання зроблено висновок, щзо сьогодні воно є компромісом між інтеграцією і диференціацією через нерозв'язаність основного завдання, яким є задоволення різних освітніх потреб дітей в інклюзивному класі на уроці. Тому у наданні освітніх послуг дітям з ООП інклюзивне навчання використовує досвід диферениійованого навчання. Запозичення досвіду інклюзивного навчання водночас є запозиченням загалом досвіду навчання дітей з ООП.

Обтрунтовано переваги вітчизняного досвіду навчання і розвитку дітей з ООП, побудованого на методологічних засадах культурно-історичної теорії розвитку психіки, зокрема положенні про рівень актуального розвитку $і$ зону найближчого розвитку дитини, та неприйнятність його руйнування через некритичне використання зарубіжного досвіду.

Очінено як недостатні розроблені в Украӥні рівні надання допомоги дітям із різними типами освітніх труднощзів у системі інклюзивного навчання.

Обгрунтовано ефективність інклюзивного навчання для дітей, інтелектуальний розвиток яких наближається до нормативного, та актуальність корекційно-педагогічної допомоги дітям раннього і дошкільного віку.

Запропоновано та обгрунтовано доцільність поєднання спечіальних й інклюзивних класів як єдиної системи у закладах загальної середньої освіти, здатної гнучко реагувати на освітні потреби дітей.

Наголошено на необхідності вивчення ефективності різних форм навчання дітей з ООП, щзо ближчим часом повинно стати предметом спеціальних досліджень.

Ключові слова: інклюзивне навчання, спеціальне навчання, категорії (типи) освітніх труднощуів, освітні послуги, рівень актуального $і$ зона найближчого розвитку.

\section{Tamara ILLYASHENKO}

Ph.D. in Psychology, Senior Researcher, Leading Researcher, Ukrainian Scientific and Methodological Center for Practical Psychology and Social Work, Vito-Litovsk Lane, 98A, Kyiv, Ukraine, 03045

ORCID: 0000-0002-5954-6177

To cite this article: Illyashenko, T. (2021). Problemy vprovadzhennia inkliuzyvnoho navchannia ditei z osoblyvymy osvitnimy potrebamy $\mathrm{v}$ Ukraini [Issues of inclusive education implementation in children with special educational needs in Ukraine]. Acta Paedagogica Volynienses, 5, 150-157, doi: https://doi.org/10.32782/apv/2021.5.23 


\section{ISSUES OF INCLUSIVE EDUCATION IMPLEMENTATION IN CHILDREN WITH SPECIAL EDUCATIONAL NEEDS IN UKRAINE}

This paper examines issues of organizational and methodological support of inclusive education in children with special educational needs (SEN). Approach of inclusive education is being actively implemented in Ukraine.

Based on the analysis and generalization of research and publications, the article establishes imperfections in today's inclusive education system in Ukraine, caused mainly by economic, organizational and methodological factors, as well as difficulties in extrapolation and adapting of foreign experience in local conditions. In this regard, the paper aims to analyze the state of organizational and methodological support of inclusive education in Ukraine and make suggestions for its optimization.

Assessing worldwide experience of inclusive education presented in works of domestic researchers, this paper considers today's status of inclusive education a compromise between integration and differentiation, due to the unresolved main task which is to meet different educational needs of children in inclusive classrooms. Therefore, in provision of educational services to children with SEN, inclusive education relies on experience of differentiated learning. Adoption of inclusive education practice is at the same time an adoption of overall experience in teaching children with SEN.

Article substantiates advantages of domestic experience in teaching and development of children with SEN, the experience based on methodological principles of cultural and historical theory of mental development; in particular, the concepts of actual development level and area of child's closest development level, the concepts that are considered crucial to adhere to while applying foreign experience.

Assistance provided in Ukraine to children with different types of learning difficulties within the system of inclusive education is assessed as insufficient.

Effectiveness of inclusive education for children whose intellectual development is close to norms, as well relevance of correctional and pedagogical assistance to children of early and preschool age who require it, are addressed.

Present work also argues for expediency of combining special and inclusive classes as integral system in secondary schools since such system can flexibly respond to children's learning needs.

Further study on efficiency of various forms of education for children with SEN is emphasized and outlined as a subject for special research in near future.

Key words: inclusive education, special education, categories (types) of learning difficulties, educational services, actual development level and area of child's closest development level.

Актуальність проблеми. Інклюзивне навчання охоплює різні категорії осіб з особливими освітніми потребами (ООП) і відповідно має відмінності в організаційно-методичних засобах його реалізації. У цій статті йтиметься про інклюзивне навчання дітей із порушеннями психофізичного розвитку, яке сьогодні в Україні активно і швидкими темпами впроваджується та розглядається як пріоритетне. Відбувається грунтовне реформування спеціального навчання дітей цієї категорії, яке складалося протягом багатьох десятиліть. Впровадження нової, інклюзивної форми навчання робить гостро актуальним розроблення організаційного, науково-методичного, кадрового його забезпечення та оцінку його ефективності.

Аналіз останніх досліджень і публікацій. Процес упровадження інклюзивного навчання названої категорії дітей з ООП супроводжується чималою кількістю досліджень, у яких висвітлюються проблеми, які постають на цьому шляху, та здійснюються пошуки методичних підходів щодо їх подолання (Заярнюк, 2015; Снісаренко , 2017; Продіус, 2019; Садова, 2020) Зокрема, відзначається недосконалість сьогоднішніх умов інклюзивного навчання в Україні, яка пов'язується з недостатнім його фінансуванням, недостатньою розробленістю нормативно-правової бази, неготовністю педагогів закладів загальної середньої освіти до роботи 3 дітьми з ООП, великою наповнюваністю інклюзивних класів, недостатньою адаптацією середовища для навчання окремих категорій дітей (Снісаренко, 2017; Заярнюк, 2015). Наголошується на неспроможності сьогоднішніх закладів освіти забезпечити диференційоване викладання в інклюзивному класі, яке могло б задовольнити освітні потреби дитини з ООП, тому індивідуальна програма розвитку (IПР) та індивідуальний навчальний план (IHП) хоч і розробляються, проте не реалізуються (Снісаренко, 2017).

Труднощі впровадження інклюзивного навчання в Україні пов'язуються з екстраполяцією зарубіжного досвіду, який важко пристосовується до реалій українського суспільства, особливо в методологічному плані (Снісаренко, 2016).

У процесі вивчення зарубіжного досвіду інклюзивного навчання (Продіус, 2019; Садова, 2020) зроблено важливі висновки: по-перше, звернено увагу на те, що перехід від диференціальної освіти до інклюзії здійснюється у країнах Західної Європи впродовж економічного 
розквіту, який забезпечив ії підтримку не тільки політично, але й фінансово, по-друге, наголошено на тому, що «інклюзивна освіта є частиною освітньої та загальної соціальної політики будь-якої держави і неминуче відображає ії специфіку, внутрішню логіку й напрям розвитку» (Садова, 2020: 189). У зв'язку з цим висловлюється застереження від «насадження скопійованої моделі в непідготовлені для цього навчальні заклади» (Продіус, 2019: 92).

Узагальнення досвіду США та деяких країн Європи показало, що найсуттєвішими проблемами, які не дозволяють швидкими темпами впроваджувати інклюзивне навчання дітей з ООП, є неготовність учителя закладу загальної освіти до нового виду професійної діяльності і нової відповідальності та потреба грунтовної перебудови усього процесу освіти, який складався протягом десятиліть, для забезпечення різних освітніх потреб дітей в інклюзивному класі (Назарова, 2010).

Серед важливих чинників ефективності інклюзивного навчання називається посилення ролі раннього втручання та підвищення якості співпраці з батьками (Назарова, 2010; Садова, 2020).

Отже, виокремлені низкою дослідників фактори, які ускладнюють упровадження інклюзивного навчання, здебільшого пов'язують із потребою трансформації усталеної системи освіти та пристосування іiі до потреб дітей з ООП, що вимагає тривалих зусиль і значних коштів, та врахування специфіки доробку країни в галузі освіти, зокрема освіти дітей з ООП.

Метою цісї статті $\epsilon$ аналіз стану організаційно-методичного забезпечення інклюзивного навчання в Україні та внесення пропозицій щодо його оптимізації.

Найсуттєвішою проблемою, без розв'язання якої неможлива розбудова якісного інклюзивного навчання, є задоволення різних освітніх потреб учнів в інклюзивному класі. Висвітлення світової практики інклюзивного навчання у працях вітчизняних дослідників (Колупаєва, 2009; Продіус, 2019; Садова, 2020) переконує, що це питання досі залишається нерозв'язаним навіть у тих країнах, які давно стали на шлях впровадження інклюзії та мають змогу вкладати в неї значні кошти. Досі усі методичні знахідки обмежуються різними формами компромісу між інтеграцією і диференціацією. Свід- ченням цього є надання педагогічних послуг дітям з ООП поза уроком чи, у кращому разі, на уроці з участю різних педагогів (Колупаєва, 2009; Продіус, 2019). Отже, урок в інклюзивному класі не $є$ таким, який може задовольняти різні освітні потреби дітей, і доводиться окремо звертатися до такого навчання дітей з ООП, яке більше відповідає іхнім потребам чи, інакше кажучи, можливостям засвоєння навчального матеріалу. Саме це і є поступкою диференційованому навчанню, яке у різних країнах має свою історію розвитку і свої досягнення та суттєво впливає на якість надання дітям з ООП освітніх послуг у системі інклюзивного навчання. Тому разом із запозиченням досвіду останнього неминуче запозичується і весь досвід диференційованого навчання.

Потрібно визнати, що вітчизняна практика диференційованого навчання дітей з ООП (3 психофізичними порушеннями) має низку переваг, які полягають у спеціальних програмах та методах корекційно-педагогічної роботи 3 різними категоріями дітей, побудованих на визначальних, положеннях про рівень актуального розвитку дитини і зону іiі найближчого розвитку (Выготский, 1935).

Копіювання зарубіжного досвіду інклюзивного навчання змушує відмовлятися від названих переваг та руйнувати вітчизняні засади навчання і розвитку дітей з ООП.

Викладені у найбільш вичерпному методичному керівництві щодо організації інклюзивного навчання в Україні (Порошенко, 2018) зарубіжні наукові розробки переконують, що їх запровадження тягне за собою і прийняття цілої системи науково-теоретичних поглядів у галузі педагогічної та спеціальної психології і відмову від таких вітчизняних, а також грунтовної перебудови освітньої практики. Якщо припустити доцільність такої перебудови, то вона потребувала би, принаймні, невизначено тривалого часу.

За умови відсутності спеціальної програми навчання дітей з ООП у країнах, досвід яких ми переймаємо, та адаптації і модифікації єдиної освітньої програми відповідно до розвитку дитини з ООП, недоліки інклюзивного навчання виступають не так виразно. Інша справа, коли, використовуючи зарубіжний досвід, вітчизняна практика фактично змушена відмовлятися від спеціальних програм, розроблених для різних категорій дітей з ООП (із порушеннями психо- 
фізичного розвитку). Тоді з усією очевидністю постають ті втрати, яких зазнають ці особливі діти в інклюзивних умовах.

Сьогодні в Україні застосування в інклюзивних класах для всіх дітей єдиної освітньої програми виправдовують задекларованими завданнями рівного доступу до якісної освіти усіх дітей. Проте спеціальні програми, розроблені на основі Державного стандарту освіти, торкаються не змін у іiї якості і змісті, а тих методичних засобів, які роблять її справді доступною для всіх категорій дітей з ООП. Слушно зауважити також, що адаптація і модифікація програми закладу загальної середньої освіти відповідно до потреб кожної дитини з ООП пов'язані з більшими ризиками відійти від іiї змісту.

Побудовані на зарубіжному досвіді методичні розробки орієнтовані на програму, за якою навчається більшість дітей в інклюзивному класі. Тривале спостереження дитини, перш ніж скласти іiі ІПР й ІНП, відбувається у процесі іiі навчання за програмою для дітей із нормативним розвитком (Таранченко \& Найда, 2012; Софій, 2015: 174). Вивчення дитини у таких умовах у кращому разі може дати відомості про рівень іiї актуального розвитку, а не про зону найближчого розвитку, яка відображає iii дійсні можливості. Побудоване на таких засадах навчання йде за розвитком дитини, а не розвиток за навчанням, що суперечить основним положенням вітчизняної педагогічної i, зокрема, спеціальної психології про навчання і розвиток дитини, які спираються на культурно-історичну теорію розвитку психіки, визнану у світі.

Необхідним для подальшого розвитку дитини $є$ такий початок її навчання, коли, спираючись на її актуальний (стартовий) розвиток, працюють із зоною найближчого розвитку. Саме з цією метою у спеціальній програмі передбачено пропедевтичний період навчання, «дозування» навчального матеріалу, темп його засвоєння і методи викладання. Інклюзивне навчання в сьогоднішній його формі не може забезпечити дитині цих умов, отже, не може забезпечити і іiі розвитку.

Початок навчання на базі складнішого матеріалу, який виходить за межі зони найближчого розвитку дитини з ООП, не дозволяє включити ii у навчальну діяльність, отже, й стимулювати подальший розвиток. Чим більше актуальний розвиток дитини з ООП відстає від актуального розвитку іiі однокласників із нормативним розвитком, тим менш сприятливими будуть умови iii навчання і тим більші втрати вона терпітиме в освіті і розвитку на уроці у сьогоднішньому інклюзивному класі. Не випадково у тих країнах, які, запроваджуючи інклюзивне навчання, не відмовляються від спеціального, дуже обережно ставляться до інклюзії дітей із порушеннями інтелектуального розвитку.

За відомостями, які наводить А.А. Колупаєва (Колупаєва, 2009: 60, 110), у Голландії 70\% від загальної кількості школярів, які перебувають у системі спеціальної освіти, - це діти 3 розумовою відсталістю та труднощами у навчанні. У Литві, яка стала на шлях упровадження інклюзивного навчання ще на початку століття, із загальної кількості дітей, які навчалися в інклюзивних умовах, 58,9\% становили діти 3 порушеннями мовлення, тоді як дітей із розумовою відсталістю було всього 5,7\% . Зате для таких дітей у цій маленькій країні функціонувало 30 спеціальних шкіл.

Інклюзивне навчання у нашій країні почалося саме 3 цих дітей, оскільки вони значно менше потребують витрат на створення безбар'єрного простору, який здебільшого розуміють як фізичний доступ до шкільного приміщення та пересування в ньому, ніж діти 3 порушеннями опорно-рухового апарату чи сенсорними порушеннями (Заярнюк, 2015; Снісаренко, 2017).

У наших сьогоднішніх умовах інклюзивного навчання можуть ефективно навчатися ті діти з ООП, які мають інтелектуальний розвиток, близький до нормативного, і можуть успішно працювати на уроці разом з усім класом, користуючись необхідною їм підтримкою, включаючи за потреби й асистента дитини. До таких умов навчання протягом дошкільного дитинства можна підготувати певну частину дітей 3 порушенням опорнорухового апарату (у тому числі з інвалідністю), 3 легкими порушеннями зору і слуху, частину дітей із ЗПР та 3 порушеннями мовлення.

Сьогодні неможливість задовольнити освітні потреби більшості дітей з ООП на уроці в інклюзивному класі, як уже зазначалося, змушує переносити їхню освіту і розвиток із малоефективного уроку на індивідуальні заняття. I тут теж виникає чимало проблем не тільки організаційно-методичного змісту, але й економічного. 
Саме потребою упорядкування і планування кількості годин індивідуальних корекційно-розвиткових занять для дітей $з$ ООП у системі інклюзивного навчання зумовлені нещодавно прийняті постановою Кабінету міністрів України категорії (типи) особливих освітніх потреб (труднощів) у осіб з особливими освітніми потребами та рівнів підтримки в освітньому процесі в інклюзивних класах (групах) закладів освіти (Положення про інклюзивно-ресурсний центр, 2017).

Спроба розглянути можливості впровадження розроблених нині як типів освітніх труднощів, так і рівнів підтримки дітей 3 відповідними труднощами виявляє низку нез'ясованих питань та суперечностей. Так, на нашу думку, неприйнятним для практики $\epsilon$ непослідовність у виявленні освітніх труднощів найлегшого (першого) рівня та в організації надання підтримки таким дітям в освітньому процесі. 3 одного боку, не передбачена комплексна оцінка розвитку таких дітей в інклюзивно-ресурсному центрі (ІРЦ), а виявлення їхніх освітніх труднощів обмежується тільки силами закладу освіти. 3 другого боку, для них передбачено розроблення IHП, логічно пов'язаного з індивідуальною освітньою траєкторією, відповідною адаптацією програми навчання, що загалом становить властивий для інклюзивного навчання комплекс заходів, які потребують відповідного фінансування. Цьому рівню підтримки дітей з ООП в освітньому процесі у фінансуванні відмовлено, що не може не позначитися негативно і на якості підтримки. Пояснити таке непослідовне ставлення до першого рівня освітніх труднощів можна тільки прагненням зменшити навантаження на державний бюджет, оскільки діти з легкими освітніми труднощами є найчисленнішою групою серед усіх дітей з ООП, і витрати навіть на мінімальну підтримку їх у процесі інклюзивного навчання можуть бути доволі відчутними. Проте це - небезпечна політика, яка залишає велику частину дітей, які мають усі можливості за належної підтримки здобути якісну освіту та високий рівень соціально-трудової адаптації, терпіти хронічну неуспішність у навчанні та через неї бути відкиненими у класному колективі, а надалі маргіналізуватися у суспільстві.

Зауважимо, що легкі освітні труднощі не $є$ легкими для діагностики їхніх причин та подолання, тому для їх виявлення потрібно застосовувати повний комплекс методичних засобів, якими володіє ІРЦ. Отже, якщо діти 3 першим рівнем освітніх труднощів включені до таких, що мають ООП, то необхідна комплексна оцінка їхнього розвитку та фінансово забезпечена відповідна допомога у процесі здобуття ними освіти. Якщо ж така допомога виключена, то логічно було б виключити цих дітей з числа таких, що мають ООП.

Ще одним важливим питанням для розроблення названих методичних рекомендацій $\epsilon$ визначення освітніх труднощів у конкретної дитини та рівня ії підтримки в освітньому процесі. Перелічені освітні труднощі можуть по-різному поєднуватися у окремих дітей і відповідно до вітчизняних психолого-педагогічних підходів перебувати у взаємозв'язку як первинні, вторинні тощо. (Выготский, 1983). Важливим для побудови надання допомоги дитині в освітньому процесі $\epsilon$ визначення первинних труднощів (порушень), від яких залежить стратегія подолання вторинних. Розглядати усі названі освітні труднощі як конгломерат окремих труднощів непродуктивно, бо таким чином губиться особистість дитини із причинно-наслідковою зумовленістю її особливостей.

Сьогоднішні умови інклюзивного навчання різною мірою можуть задовольнити освітні потреби дітей з різними типами освітніх труднощів.

Включити в освітній процес на уроці в інклюзивному класі можливо дітей з ООП, які мають порівняно легкі труднощі - першого і другого ступеня прояву, - за умови надання їм відповідної підтримки. Для дітей, які мають труднощі тяжкого і найтяжчого ступеня прояву, фактично передбачено індивідуальне навчання 3 відвідуванням окремих заходів закладу освіти. Для багатьох таких дітей 6-8 годин на тиждень буде недостатньо.

Проте у найтяжчих умовах будуть перебувати діти, які мають труднощі помірного ступеня прояву. Передбачене навчання їх в інклюзивному класі за розкладом і програмою для дітей 3 нормативним розвитком навіть 3 адаптацією і модифікацією останньої відповідно до ІПР і ІНП конкретної дитини за сьогоднішніх методичних можливостей буде малоефективним і не зможе компенсуватися 3 допомогою чотирьох годин індивідуальних занять. Водно- 
час діти 3 такою категорією труднощів у процесі навчання становлять значну частину серед усіх тих, що мають психофізичні порушення.

Загалом, оцінюючи перспективу застосування категорій освітніх труднощів дітей з ООП та рівнів їх підтримки в освітньому процесі, скажемо, що вони внесуть більші обмеження у надання освітніх послуг дітям з ООП порівняно $з$ тими, що діяли досі, і це ще більше загострить названі вище суттєві проблеми ефективності інклюзивного навчання.

Зазвичай головним аргументом на користь пріоритетності цієї форми навчання висувається потреба соціальної інтеграції дітей з ООП. Проте в інтересах освіти і розвитку дітей цієї категорії потрібно розвести поняття соціального виховання, яке, безумовно, повинно бути інклюзивним і сприяти інтеграції дітей з ООП у суспільстві, і навчання, якість якого визначається його спроможністю забезпечити освіту і розвиток дитини з ООП. Умови навчання, які не слугують освіті й розвитку дитини, не можуть слугувати ії соціальній інтеграції. В умовах недосконалого інклюзивного навчання створюються високі ризики завдати непоправної шкоди розвитку дітей, а отже, й можливостям їхньої соціальної інклюзії.

Висновки і пропозиції. Здійснений аналіз стану впровадження інклюзивного навчання дітей з ООП в Україні дозволяє зробити низку висновків і пропозицій.

Насамперед потрібно визнати, що інклюзивне навчання дітей з ООП сьогодні не може бути пріоритетним, а темпи його впровадження форсованими, оскільки його матеріально-технічне оснащення та розвиток відповідних освітніх технологій $\epsilon$ недостатніми для забезпечення його ефективного функціонування.

$\mathcal{E}$ неприйнятною некритична й однобічна екстраполяція зарубіжного досвіду інклюзивного навчання у вітчизняні умови та знецінення і руйнування вітчизняного досвіду освіти і розвитку дітей з ООП, який дає достатній простір для пошуку поєднання якісної освіти дітей цієї категорії та їхньої соціальної інтеграції.

Як один із можливих способів забезпечення якісної освіти і розвитку дітей з ООП та сприяння їхній соціальній інтеграції пропонуємо поєднання спеціального й інклюзивного навчання як єдиної системи, на обгрунтуванні якої зупинимося далі.
Насамперед як єдину систему ми розглядаємо поєднання спеціальних й інклюзивних класів (груп) у закладах дошкільної і загальної середньої освіти.

Досі спеціальні й інклюзивні класи (групи) діють як альтернативні. До того ж останнім часом вони перебувають у нерівних умовах, оскільки виразна орієнтація державної політики на інклюзивне навчання та посилене його пропагування серед батьківської громадськості сприяє витісненню спеціальних класів. Водночас практика їх не заслуговує знецінення, a порівняння умов навчання інклюзивному класі і в спеціальному робить очевидними переваги останнього.

По-перше, спеціальний клас працює за спеціальною програмою, яка сьогодні здатна найкраще задовольнити особливі освітні потреби дітей. По-друге, ще однією перевагою спеціального класу $є$ зменшена у ньому (більше, ніж удвоє, порівняно з інклюзивним) кількість дітей, яка забезпечує необхідну індивідуалізацію педагогічної роботи 3 кожною дитиною. По-третє, суттєве значення для ефективного керівництва навчанням і розвитком дітей має i те, що реальнішим є забезпечення відповідної підготовки педагога до роботи у спеціальному класі. По-четверте, функціонування спеціальних класів у закладах загальної середньої освіти створює умови для різних форм спілкування дітей з ООП з дітьми 3 нормативним розвитком та дозволяє їм навчатися за місцем проживання, що є і кроком до соціальної інклюзії.

I спеціальні, й інклюзивні класи зможуть функціонувати набагато ефективніше, якщо вони 3 альтернативних перетворяться на єдину освітню систему для задоволення освітніх потреб дітей з ООП та їх соціальної інтеграції.

Функціонування цих двох форм навчання дітей з ООП як єдиної системи дозволяє гнучко реагувати на освітні потреби дитини, яка може починати навчання у спеціальному класі, а у міру розвитку і набуття компетентностей та здатності працювати на уроці разом 3 дітьми 3 нормативним розвитком продовжуватиме його в умовах інклюзії. Так само діти, для яких інклюзивне навчання виявилося неефективним, повинні мати можливість надалі навчатися у спеціальному класі.

Тільки за таких умов набуде сенсу моніторинг динаміки розвитку дитини не рідше, ніж двічі 
на рік, як зазначено у Положенні про ІРЦ (Положення про інклюзивно-ресурсний центр, 2017). Сьогодні здійснення моніторингу на основі оцінки виконання IПР і ІНП в умовах інклюзивного навчання та їх спрощення у разі виявлених негативних показників загрожує помилковими висновками про можливості розвитку дитини, бо причина іiі неуспішності може бути у неадекватності умов навчання, а не обмежених потенційних можливостях розвитку. Доцільнішим у таких випадках буде продовження іії навчання у спеціальному класі і виявлення та реалізація таким чином справжніх іiі можливостей.

Включення дітей 3 ООП у сьогоднішне інклюзивне навчання повинно бути зваженим і вибірковим залежно від особливостей їхніх пізнавальних функцій. Пріоритетною в кожному окремому випадку повинна бути така траєкторія здобуття дитиною освіти, яка дозволить ій адаптуватися до життя в соціумі з меншими втратами.

В умовах сьогоднішнього недостатнього методичного забезпечення інклюзивного навчання воно може бути ефективним тільки для дітей, які можуть із більшою чи меншою допомогою скористатися фронтальною роботою педагога із класом на уроці.
Для дітей, інтелектуальний розвиток яких стабільно залишається значно нижчим від нормативного, ефективнішим буде навчання у спеціальному класі. Для їхньої соціальної інтеграції перспективним $€$ впровадження різних форм часткової інклюзії, коли вони об'єднуються зі своїми ровесниками 3 нормативним розвитком на заняттях $з$ окремих предметів і на позаурочних заходах (Малофеев \& Шматко, 2008).

Виявлення та охоплення корекційнопедагогічною допомогою дітей з ООП у ранньому і дошкільному віці, а також, за потребою, початок їхнього навчання у спеціальному класі зможе підготувати значну їх частину до подальшого успішного навчання в інклюзивних умовах.

Налагоджене функціонування спеціальних та інклюзивних класів як єдиної системи дозволило би зберегти кращі здобутки вітчизняної спеціальної освіти та сприяти соціальній інтеграції дітей з ООП.

Доцільність різних форм навчання дітей з ООП може бути об' єктивно оцінена і виправдана тільки через ретельно організоване порівняльне вивчення їхньої ефективності, що найближчим часом повинно стати предметом спеціальних досліджень.

\section{ЛITЕРАТУРA:}

1. Выготский Л.С. Собрание сочинений : в 6 т. / гл. ред. А.В. Запорожец. Москва : Педагогика, 1982-1984. Т. 5 : Основы дефектологии / под. ред. Т.А. Власовой. 1983. 369c. С. 257-321. URL: http://elib.gnpbu.ru/text/vygotsky_ ss-v-6tt_t5_1983/ (дата звернення: 14.10.2021).

2. В Выготский Л.С. Умственное развитие детей в процессе обучения: Сборник статей. М.-Л. : Государственное учебно-педагогическое издательство, 1935. 136 c. URL: http://psychlib.ru/inc/absid.php?absid=9980 (дата звернення: 14.10.2021).

3. Заярнюк О.В. Інклюзивна освіта в Україні: проблем и та шляхи їх вирішення. Науковий вісник Міжнародного гуманітарного університету. Серія: Економіка і менеджмент. 2015. Вип. 11. С. 190-193.

4. Колупаєва А.А. Інклюзивна освіта: реалії та перспективи : монографія. Київ : «Самміт-Книга», 2009. 272 с. : іл. (Серія «Інклюзивна освіта»).

5. Малофеев Н.Н., Шматко Н.Д. Базовые модели интегрированного обучения. Дефектология. 2008. № 1. С. 71-78.

6. Назарова Н. Интегрированное (инклюзивное) образование: генезис и проблемы внедрения. Социальная педагогіка. 2010. № 1. С. 77-87.

7. Організаційно-методичні засади діяльності інклюзивно-ресурсних центрів: навчально-методичний посібник / За заг. ред. М.А. Порошенко та ін. Київ : 2018. 252 c. URL: https://mon.gov.ua/storage/app/media/inkluzyvnenavchannya/posibniki/Inclusive_study_Sep17.pdf (дата звернення: 14.10.2021).

8. Положення про інклюзивно-ресурсний центр : Постанова Кабінету Міністрів України від 12 липня 2017 p. № 545 https://zakon.rada.gov.ua/laws/show/545-2017-\%D0\%BF\#Text (дата звернення: 14.10.2021).

9. Продіус О.І. Особливості моделей інклюзивної освіти в країнах Європи відповідно до вимог сучасного суспільства. Проблеми системного підходу в економіщі. 2019. Вип. 4 (72). С. 86-93.

10. Садова I.І. Інклюзивна освіта в країнах Європи. Педагогіка формування творчої особистості у вищій $i$ загальноосвітній школах. 2020. № 69. Т. 1. С. 188-192.

11. Снісаренко O.I. Диференціація як система навчання інтегрованих учнів в загальноосвітньому закладі. Науковий часопис Національного педагогічного університету імені М.П.Драгоманова. Серія 19: Корекиійна педагогіка та спеиіальна психологія. 2017. Вип. 33. С. 74-82. 
12. Снісаренко О.І. Стратегія диференціації навчання інклюзивних учнів із затримкою психічного розвитку в умовах загальноосвітнього закладу. Актуальні питання корекційної освіти. 2017. Вип. 10. С. 327-341.

13. Софій Н.З. Особливості викладання в інклюзивному навчальному середовищі: практика спільного викладання. Освіта осіб з особливими потребами: шляхи розбудови. 2015. Вип. 10. С. 173-177.

14. Таранченко О.М., Найда Ю.М. Диференційоване викладання в інклюзивному класі: навчально-методичний посібник / за заг. ред. Колупаєвої А.А. Київ : «А.С.К.», 2012. 124 с.

\section{REFERENCES:}

1. Vygotskij, L.S. (1983). Sobranie sochinenij [Collected Works]. (Vols. 1-6). Moskva : Pedagogika [in Russia].

2. Vygotskij, L.S. (1935). Umstvennoe razvitie detej v processe obucheniya [The mental development of children in the learning process]. Moskva - Leninggrad : Gosudarstvennoe uchebno-pedagogicheskoe izdatel'stvo [in Russia].

3. Zaiarniuk, O.V. (2015). Inkliuzyvna osvita v Ukraini: problem y ta shliakhy yikh vyrishennia [Inclusive education in Ukraine: problems and ways to solve them]. Naukovyi visnyk Mizhnarodnoho humanitarnoho universytetu - Scientific Bulletin of the International Humanities University, 11, 190-193 [in Ukrainian].

4. Kolupaieva, A.A. (2009). Inkliuzyvna osvita: realii ta perspektyvy [Inclusive education: realities and prospects]. Kyiv : «Sammit-Knyha» [in Ukrainian].

5. Malofeev, N.N., \& SHmatko, N.D. (2008). Bazovye modeli integrirovannogo obucheniya [Basic Integrated Learning Models]. Defektologiya - Defectology, 1, 71-78 [in Russia].

6. Nazarova, N. (2010). Integrirovannoe (inklyuzivnoe) obrazovanie: genezis i problemy vnedreniya [Integrated (inclusive) education: genesis and implementation problems]. Social'naya pedagogika - Social pedagogy, 1, 77-87 [in Russia].

7. Poroshenko, M.A. (Eds.). (2018). Orhanizatsiino-metodychni zasady diialnosti inkliuzyvno-resursnykh tsentriv [Organizational and methodological principles of inclusive resource centers]. Kyiv [in Ukrainian].

8. Polozhennia pro inkliuzyvno-resursnyi tsentr : Postanova Kabinetu Ministriv Ukrainy vid 12 lypnia 2017 r. № 545 [Regulations on the Inclusive Resource Center : Resolution of the Cabinet of Ministers of Ukraine of July 12, 2017 № 545]. (n.d.).zakon.rada.gov.ua. Retrieved from: https://zakon.rada.gov.ua/laws/show/545-2017-\%D0\%BF\#Text [in Ukrainian].

9. Prodius, O.I. (2019). Osoblyvosti modelei inkliuzyvnoi osvity v krainakh Yevropy vidpovidno do vymoh suchasnoho suspilstva [Features of models of inclusive education in European countries in accordance with the requirements of modern society]. Problemy systemnoho pidkhodu $v$ ekonomitsi - Problems of system approach in economy, 4 (72), 86-93 [in Ukrainian].

10. Sadova, I.I. (2020). Inkliuzyvna osvita v krainakh Yevropy [Inclusive education in European countries]. Pedahohika formuvannia tvorchoi osobystosti u vyshchii i zahalnoosvitnii shkolakh - Pedagogy of creative personality formation in higher and general education schools, 69, 188-192 [in Ukrainian].

11. Snisarenko, O.I. (2017). Dyferentsiatsiia yak systema navchannia intehrovanykh uchniv v zahalnoosvitnomu zakladi [Differentiation as a system of teaching integrated students in a secondary school]. Naukovyi chasopys Natsionalnoho pedahohichnoho universytetu imeni M.P.Drahomanova. Seriia 19: Korektsiina pedahohika ta spetsialna psykholohiiaScientific journal of the National Pedagogical University named after MP Drahomanov. Series 19: Correctional pedagogy and special psychology, 33, 74-82 [in Ukrainian].

12. Snisarenko, O.I. (2017). Stratehiia dyferentsiatsii navchannia inkliuzyvnykh uchniv iz zatrymkoiu psykhichnoho rozvytku v umovakh zahalnoosvitnoho zakladu [Strategy of differentiation of education of inclusive students with mental retardation in the conditions of a general educational institution]. Aktualni pytannia korektsiinoi osvity - Current issues of correctional education, 10, 327-341 [in Ukrainian].

13. Sofii, N.Z. (2015). Osoblyvosti vykladannia v inkliuzyvnomu navchalnomu seredovyshchi: praktyka spilnoho vykladannia [Features of teaching in an inclusive learning environment: the practice of co-teaching]. Osvita osib $z$ osoblyvymy potrebamy: shliakhy rozbudovy - Education of people with special needs: ways of development, 10, 173-177 [in Ukrainian].

14. Taranchenko, O.M., \& Naida, Yu.M. (2012). Dyferentsiiovane vykladannia v inkliuzyvnomu klasi [Differentiated teaching in an inclusive classroom]. A.A Kolupaieva (Ed.). Kyiv : «A.S.K.» [in Ukrainian]. 